\title{
Accessing and educating female sex workers in Ukraine via a peer-driven intervention
}

\author{
Oksana Matiyash*, Pavlo Smyrnov, Robert Broadhead \\ From 17th International Symposium on HIV and Emerging Infectious Diseases (ISHEID) \\ Marseille, France. 23-25 May 2012
}

\section{Introduction}

A peer-driven intervention (PDI) for female sex workers (FSWs) was implemented in harm reduction projects in two Ukrainian cities. The goal was to recruit and interview $500 \mathrm{FSW}$ in 6 months who had never received services before, and to measure how well FSW-recruiters educated FSWs in a body of fresh HIV prevention information. Recruiters were rewarded by earning tickets to win special prizes in a weekly lottery.

\section{Methods}

A PDI relies on respondent educating and recruiting peers for services. All recruits also get to serve as peereducator/recruiters. Each recruit's score on an 8-item knowledge test, measuring how well the recruiter educated her, determined how many lottery tickets the recruiter earned. A weekly lottery was held each week offering prizes to 4 lucky winners.

\section{Results}

The two PDIs in 6 months recruited 532 and 437 FSWs never seen before, 2-3 times more new FWSW-recruits than the number recruited 6 months prior to the PDIs' start-up. Both projects held 23 lotteries with an average attendance of 8 FSWs. Very significant differences in levels of drug- and sex-related risk behaviors were found between FSW drug-users and non-users, heavily shaped by education, knowledge, and other social variables, suggesting more targeted types of intervention.

\section{Conclusion}

The FSW-respondents were eager to serve as peer-educators/recruiters. The lottery proved to be a cost-saving and effective reward system that was highly motivating. The PDI offers harm reduction projects an entirely new

* Correspondence: matiyash@aidsalliance.org.ua

International HIV-AIDS Alliance-Ukraine, Kyiv, Ukraine model for accessing and educating FSWs, as well as a new method for targeting special sub-populations of FSWs.

Published: 25 May 2012

\section{doi:10.1186/1742-4690-9-S1-P118}

Cite this article as: Matiyash et al:: Accessing and educating female sex workers in Ukraine via a peer-driven intervention. Retrovirology 20129 (Suppl 1):P118.
Submit your next manuscript to BioMed Central and take full advantage of:

- Convenient online submission

- Thorough peer review

- No space constraints or color figure charges

- Immediate publication on acceptance

- Inclusion in PubMed, CAS, Scopus and Google Scholar

- Research which is freely available for redistribution
C Biomed Central

\section{Biomed Central}

(c) 2012 Matiyash et al; licensee BioMed Central Ltd. This is an Open Access article distributed under the terms of the Creative Commons Attribution License (http://creativecommons.org/licenses/by/2.0), which permits unrestricted use, distribution, and reproduction in any medium, provided the original work is properly cited. 